\title{
XÁC ĐỊNH MẠTT BIỂN TRUNG BÌNH LÀM RANH GIỚI GIŨA ĐẤT LIỀN VÀ BIỂN PHỤC VỤ CÔNG TÁC ĐỊA CHÍNH BIỂN
}

\author{
HÀ MINH HÒA \\ Viện Khoa học Đo đạc và Bản đồ
}

\section{Đặt vấn đề:}

Trong giai đoạn hiện nay, các địa phương thuộc các vùng đất thấp ngập mặn ven biển chủ yếu khai thác các vùng đất ngập mặn ven biển để nuôi trồng thủy sản. Đối với công tác quản lý nhà nước về đất đai, việc xác định ranh giới giữa đất liền và biển, đặc biệt là các vùng đất ngập mặn có khả năng nuôi trồng thủy sản, trở nên rất quan trọng phục vu công tác giao đất, cho thuê đất và phát triển công tác địa chính biển.

Vùng đất nằm dưới mưc nước biển sâu nhất (khoảng - 2m) không thich hơp cho việc nuôi trồng thủy sản. Vậy mặt biển được sủ dụng cho công tác địa chính biển là mặt nhu thế nào?. Trong bài báo này, tác giả sẽ tìm câu trả lời cho câu hỏi trên nhằm mục đỉch phát triển công tác địa chính biển.

1. Thực trạng khai thác dải ven biển để nuôi trồng thủy sản ở Việt Nam

Các loại cây trồng, vật nuôi ở các vùng ven biển chủ yếu là các thực vật, động vật sinh trưởng ở các vùng đất ngập mặn. Theo (Thực vật ngập mặn), cây vẹt sống trong nước mặn, khi thủy triều lên thì gần như phần cây sẽ bị nước biển phủ kín và thủy triều xuống thì trơ lại nguyên phần gốc. Cây Sú vẹt là một loại cây mọc ở ven biển, đặc tính sống là nửa nước và nửa cạn và sống trong điều kiện cực kỳ khắc nghiệt. Do phải sống trong điều kiện khắc nghiệt như vậy nên nó cũng tạo ra loài hoa rất đặc biệt, hoa Sú vẹt. Mật ong Sú vẹt không bị nhiễm thuốc trừ sâu, thuốc bảo vệ thực vật. Loại cây này không chỉ được sử dụng để làm thuốc nhuộm, chế biến thức ăn mà còn có khả năng điều trị bệnh tiêu chảy, ung bướu và cầm máu.

Thực vật ngập mặn hình thành một môi trường sống nước mặn của rừng cây thân gỗ và rừng cây bụi hay còn gọi là rừng ngập mặn. Rừng ngập mặn thường phân bố ở vùng ven biển tích tụ các trầm tích hạt mịn và chúng có vai trò bảo vệ các vùng đất bởi tác động của sóng năng lượng cao.
Một vài loài cây ngập mặn phát triển rễ khí sinh, còn gọi là rễ có những lỗ thông khí ngoi thẳng lên từ lớp đất bùn nước. Một vài rễ khí sinh trông giống như ống thở của thợ lặn và thường vươn lên khỏi mặt nước hoặc bùn khoảng $30 \mathrm{~cm}$ (như rễ của cây mắm). Cây trên cạn không sống được nơi đất ngập mặn do thiếu oxy làm quá trình hô hấp ngưng trệ. Biện pháp đầu tiên có thể đáp ứng việc canh tác lúa trên đất mặn là thay đổi môi trường để thích hợp cho cây lúa sinh trưởng và phát triển. Biện pháp này bao gồm các công việc kỹ thuật chủ yếu trong quá trình cải tạo đất giảm độ mặn, do đó đòi hỏi nhiều tài nguyên đầu vào, chi phí cao nên rất khó đáp ứng đối với nông dân bình thường. Biện pháp quan trọng tiếp theo, đó là chọn lọc giống lúa có khả năng chịu mặn hoặc thay đổi cấu trúc gen của cây lúa để có thể thích ứng với vùng trồng nhiễm mặn. Đây là khả năng có triển vọng, ít tốn kém và là biện pháp được chấp nhận về mặt kinh tế và xã hội. Một người nông dân ở An Giang đã phát triển trồng lúa, thanh long trên vùng mặn.

Những năm gần đây, việc nuôi tôm trên vùng đất cát ngập mặn được phát triển mạnh ở khu vực miền Trung, Đồng bằng sông Cửu Long. 
Theo (Nguyễn Thị Phương Lan, 2003), vùng đất cát thường hấp thụ năng lượng bức xạ nhiệt của mặt trời rất lớn nên nhiệt độ cao, độ ẩm thấp, nên ao nuôi tôm trên cát phải có độ sâu từ $1,4-1,5 \mathrm{~m}$, độ mặn 18 - 25, nhiệt độ $28-30^{\circ} \mathrm{C}$, độ pH 7,5 8,5 , độ trong của nước 0,3 - 0,4, oxy hòa tan 4 $9 \mathrm{mg} / \mathrm{l}$, chế độ bón phân hợp lý. Đối với việc nuôi tôm trên cát, trong một ngày đêm khi thủy triều lên xuống, đáy của đất nuôi tôm phải đảm bảo nằm dưới ánh nắng mặt trời khoảng $13 \mathrm{~h}$.

Những cây trồng, vật nuôi được nêu ở trên không thích ứng với mặt biển sâu nhất trung bình. Chúng chủ yếu sinh trưởng ở các vùng đất ven biển nửa nước, nửa cạn.

\section{Thực tế sử dụng các mặt biển trung bình ở các nước}

Ở nước Mỹ, theo tài liệu (Tidal datum and their application), đã quy định các mặt biển trung bình như sau:

Mực nước thấp nhất trung bình (level of Mean Lowest Low Water - MLLW) được xác định tại khu vực Các hồ lớn (the Great Lakes) bao gồm 5 hồ lớn nằm giữa Mỹ và Canada (Office of Coast Survey (NOAA)). MLLW được sử dụng để xác định đường cơ sở và hệ quy chiếu hải đồ;

Mực nước thấp trung bình (MLW) được sử dụng để xác định đường ven biển (coastline). Ở Brazil sử dụng mặt nước thấp trung bình (MLWS) để xác định đường cơ sở và hệ quy chiếu hải đồ. Vùng nằm giữa đường cơ sở và đường ven biển là vùng đất ngập nước quốc gia.

Mực nước biển trung bình (MSL) được sử dụng để nghiên cứu mặt geoid và xác định độ sâu địa hình đáy biển;

Mực nước cao trung bình (MHW) được sử dụng để xác định đường bờ biển (shoreline).

Mực nước cao cao nhất trung bình (MHHW) là trung bình số học của các độ cao cao nhất của các triều được đo trong chu kỳ 19 năm. Mực MHHW được sử dụng để xác định đường mực nước cao cao nhất trung bình nằm giữa đường bờ biển và vùng đất cao, theo đó vùng đất nằm giữa đường bờ biển và đường ven biển là vùng nước thủy triều quốc gia, còn vùng từ đường mực nước cao cao nhất trung bình lên vùng đất cao thuộc đất sở hữu tư nhân.

Theo các tài liệu (Brief introduction to vertical datums and tide levels, (2006); Turner, J.H., Iliffe, J.C., Ziebart, M.K. and Jones, C., 2013)) cơ quan Dịch vụ Thủy văn Australia (AHS) và Cơ quan thủy văn của Anh (UKHO) đã sử dụng mức MLLW làm hệ quy chiếu hải đồ.

\section{Kết luận}

Từ các kết quả phân tích ở các mục 1, 2 chúng ta thấy rằng các cây trồng, vật nuôi tại các vùng đất ngập nước ven biển tương ứng với mặt biển thấp trung bình (MLWS). Hiện nay, Tổng cục Khí tượng - Thủy văn dựa trên các trạm nghiệm triều có thời gian đo mực nước 18,6 năm mới xác định các mặt biển cao nhất trung bình (MHHWS), mặt biển trung bình (MSS) và mặt biển thấp nhất (MLLWS). Tuy nhiên, mặt biển thấp trung bình (MLWS) được sử dụng rộng rãi trong địa chính biển chưa xác định.

Với mục đích phát triển công tác địa chính biển. Đề nghị Tổng cục Quản lý đất đai nên xem xét quy định việc sử dụng mặt biển thấp trung bình (MLWS). $O$

\section{Tài liệu tham khảo}

[1]. Nguyễn Thị Phương Lan, 2003, Tạp chí KHCN Thủy sản, tháng 7.

[2]. Thực vật ngập mặn (Wikipedia).

[3]. Office of Coast Survey (NOAA). http://www.nauticalcharts.noaa.gov/mcd/learn nc_soundingdatum.html

[4]. Tidal datum and their application. NOAA Special Publication NOS CO - OPS1, Silver Spring, Maryland, June 2000, 132 p.

[5]. Brief introduction to vertical datums and tide levels, (2006), SeaZone, www.tidalcompass/

(Xem tiếp trang 22) 